\title{
Influence of silicate on particulate carbon production in phytoplankton
}

\author{
J. K. Egge*, A. Jacobsen \\ Department of Fisheries and Marine Biology, University of Bergen, Bergen High Technology Center, N-5020 Bergen, Norway
}

\begin{abstract}
A mesocosm experiment was conducted over a period of $4 \mathrm{wk}$ to examine how supply of silicate influences dominant species and biomass within the phytoplankton community. Four enclosures, filled with nutrient-depleted, post-bloom seawater, were fertilised with nitrate and phosphate, with the addition of silicate to 2 of the enclosures. The main difference in the phytoplankton community development between the 2 treatments was the occurrence of much stronger blooms of Emiliania huxleyi (Lohmann) Hay et Mohler in the 2 enclosures supplied only with nitrate and phosphate (NP1 and NP2), whereas diatoms were dominant in the 2 enclosures treated with silicate as well (NPS1 and NPS2). Phaeocystis pouchetii, which was observed primarily during the first week, disappeared in the NP enclosures, but persisted throughout the experiment, although in low numbers, in the NPS enclosures. Integrated over the whole experimental period, equal amounts of nitrate and phosphate were consumed in all 4 enclosures. Additional supply of silicate resulted in a 2 -fold increase in carbon production in the NPS enclosures $\left(6.1\right.$ and $\left.7.0 \mathrm{~g} \mathrm{~m}^{-3}\right)$ compared to the NP enclosures $\left(2.6\right.$ and $\left.3.2 \mathrm{~g} \mathrm{~m}^{-3}\right)$. For each $\mathrm{g}$ silicate supplied to the enclosures, carbon production increased by $7.4 \mathrm{~g}$. The ratio between calcification and photosynthesis (C:P), measured in the NP enclosures, reached maxima of 0.48 (NP1) and 0.42 (NP2) when the E. huxleyl bloom peaked, while the cell specific calcification ranged between 0.1 and $0.4 \mathrm{pg} \mathrm{C} \mathrm{h}^{-1}$ cell $^{-1}$ over the course of the experiment. Integrated over the experimental period, 0.5 and $0.3 \mathrm{~g} \mathrm{C} \mathrm{m}^{-3}$, in NP1 and NP2 respectively, were fixed by calcification.
\end{abstract}

KEY WORDS: Silicate Carbon Phytoplankton - Diatoms - Emiliania huxleyi Phaeocystis pouchetii

\section{INTRODUCTION}

In general, phytoplankton utilise nitrogen and phosphorus at a ratio close to $16: 1$ (Redfield et al. 1963), while silicate is required principally by diatoms and is utilised at a nitrogen:silicate (N:Si) ratio close to $1: 1$ (Stefánsson \& Richards 1963). Mesocosm experiments, which employ large plastic bags in the sea, have been used for the past $10 \mathrm{yr}$ to study the effects of artificial fertilisation (with nitrate, phosphate, and silicate) on the natural marine phytoplankton community in Norwegian coastal waters (Egge 1993, Egge \& Heimdal 1994, Rykkelid 1994, Jacobsen et al. 1995). These experiments have demonstrated that the dominant species depends highly upon the composition of nutrient additions. Diatoms are generally the dominant group, accounting for $70 \%$ or more of the cell numbers in the

\footnotetext{
•E-mail: jorun.egge@ifm.uib.no
}

community, irrespective of season (between February and September), given sufficient nutrients and a threshold concentration of approximately $2 \mu \mathrm{M}$ silicate (Egge \& Aksnes 1992, Rykkelid 1994). The success of the diatoms appears to be due to their growth rate at nonlimiting nutrient concentrations. Diatoms were not able to dominate when phosphate was deficient, even when silicate and nitrate were in excess (Egge 1993). The growth of the flagellate community appears to be less affected by low phosphate concentrations.

When nitrate and phosphate are available, and low silicate concentration prevents the growth of diatoms, the coccolithophorid Emiliania huxleyi (Prymnesiophyceae) and the colony-forming Phaeocystis pouchetii (Prymnesiophyceae) blooms. Both are wellknown bloom-forming species in Norwegian coastal waters (Eilertsen et al. 1981, Heimdal et al. 1994); dominance between the 2 species and the strength of their respective blooms depends upon season and nutrient 
composition. In mesocosms, E. huxleyi tends to be dominant over $P$. pouchetii at temperatures of $10^{\circ} \mathrm{C}$ or higher, surface irradiances of $20 \mathrm{~mol} \mathrm{~m} \mathrm{~m}^{-2} \mathrm{~s}^{-1}$ or higher (Egge \& Heimdal 1994) and at low concentrations of phosphate. If nutrients are available, $P$. pouchetii has an advantage over $E$. huxleyi at low temperatures and irradiance. When massive blooms of $P$. pouchetii have been observed at high irradiance, they have occurred following the decay of E. huxleyi blooms. Cota et al. (1994) reported adaptation of Phaeocystis to low light intensities and temperature in Greenland.

Phytoplankton generally produce organic carbon by means of photosynthesis, while coccolithophorids such as Emiliania huxleyi additionally produce inorganic carbon in the form of small extracellular scales of calcium carbonate. While free $\mathrm{CO}_{2}$ is the source of photosynthesis, bicarbonate ions are the substrate for calcification (Paasche 1964, Dong et al. 1993). Although these processes are clearly coupled, neither is an absolute prerequisite for the other; however, free $\mathrm{CO}_{2}$ produced by calcification can also be utilised for photosynthesis (Paasche 1964, 1965, Sikes et al. 1980 , Nimer \& Merrett $1 \overline{9} \overline{9} 2, i \overline{9} 9 \overline{3}$ ). The standing stock and production of particulate carbon have previously been measured for $E$. huxleyi in laboratory cultures (Paasche 1964, 1965, Balch et al. 1992, 1993), in mesocosm experiments (Bleijswijk et al. 1994, Wal et al. 1994), and in natural blooms (Balch et al. 1992, Fernández et al. 1993).

The purpose of the present study was to measure particulate carbon production in different groups of phytoplankton (diatoms and coccolithophorids), in addition to calcification by coccolithophorids, when the same amounts of nitrate and phosphate were available. As far as we are aware, this represents the first time that blooms of diatoms and coccolithophorids have been initiated simultaneously, thereby exposing both to identical environmental conditions and fluctuations.

From the perspective of eutrophication, it is clearly critical to describe how species composition and biomass respond to the composition of added nutrients. A sharp peak in production and biomass would probably result in a greater sedimentation compared to that associated with more sustained but lower production. The extent of sedimentation and grazing is important, and with regard to $\mathrm{CO}_{2}$ invasion it is also important to know whether or not particulate carbon is exported from the euphotic zone and in what form (organic or inorganic).

There have been several mesocosm experiments where blooms of Emiliania huxleyi have been initiated and studied (Egge 1993, Fernández et al. 1994. Heimdal et al. 1994, Levasseur et al. 1996). In this particular mesocosm experiment, variation in nutrient supply was used to initiate blooms of both diatoms and cocco- lithophorids, and 2 sizes of enclosures were used. Stratification was prevented in the small enclosures ( $4.3 \mathrm{~m}$ deep) by stirring in the whole water column, while in the deep enclosures $(10 \mathrm{~m})$ stratification was allowed as only the upper $4 \mathrm{~m}$ were stirred. The best control was achieved in the small enclosures, because (1) the watermasses were homogenous, and (2) the hydrodynamic conditions were similar in all enclosures both for the duration of 1 experiment, and from 1 year to another. Several processes such as carbon chemistry (Rydningen 1996), gas exchanges (D. Crawford, D. A. Purdie \& T. Johannessen unpubl.), grazing (Nejstgaard et al. 1997), and lipid content of copepods (WangAndersen 1996) were therefore measured in the small enclosures only. Phytoplankton dynamics were investigated in all enclosures, while sedimentation was measured in the deep enclosures only (P. Wassmann, J. Egge, M. Reigstad \& D. L. Aksnes unpubl.). This paper, in addition to giving a general description of the experiment, reports the results from 2 sets of duplicate small enclosures which were all given equal amounts of nitrate and phosphate, and 2 enclosures additionally suppiied with silicate. Hiere we specificdily examine the influence of the 2 treatments on species composition, carbon production and accumulation of particulate carbon.

\section{MATERIALS AND METHODS}

The experiment was carried out between 13 May and 9 June 1994 at the Marine Biological Station near Bergen, Norway (see Heimdal et al. 1994). The 4 enclosures each had a diameter of $2 \mathrm{~m}$, a volume of about $11 \mathrm{~m}^{3}$ and were made of polyethylene, which has $90 \%$ irradiance transmission (photosynthetically active radiation, PAR). The enclosures were open to the air and were secured to the southern side of a raft containing a small floating laboratory (see Fig. 1 of Egge \& Heimdal 1994). The enclosures were filled on 13 May by pumping unfiltered, nutrient-poor, post-spring-bloom water from a depth of $1 \mathrm{~m}$ in the fjord. An airlift pump was used to maintain homogeneity of the watermass inside the enclosures by circulating water from $0.5 \mathrm{~m}$ above the enclosure bottom to the surface. Two enclosures were supplied with nitrate and phosphate (NP enclosures, NP1 and NP2) and the 2 others were supplied with nitrate, phosphate and silicate (NPS enclosures, NPS1 and NPS2). Enclosures with the same nutrient supply are subsequently referred to herein as duplicate enclosures. Nitrate, phosphate and silicate were supplied from stock solutions of $\mathrm{NaNO}_{3}, \mathrm{KH}_{2} \mathrm{PO}_{4}$, and $\mathrm{Na}_{2} \mathrm{SiO}_{3} \cdot 5 \mathrm{H}_{2} \mathrm{O}$, respectively. The nutrients were added on 14 May, corresponding to an increase of $15 \mu \mathrm{M}$ nitrate, $1 \mu \mathrm{M}$ phosphate, and $5 \mu \mathrm{M}$ silicate in the 
enclosures. Beginning on 16 May, $10 \%$ of the enclosure volume was renewed daily, with water from a depth of $1 \mathrm{~m}$. Renewal water was first pumped into a tank on the raft, then fed through tubes to each of the enclosures. Nutrients were added every second day, at 12:00 h, corresponding to $20 \%$ of their initial concentrations, to compensate for nutrient loss due to water renewal. The enclosures and the surrounding seawater were sampled at 09:00 h every second day at a depth of $2 \mathrm{~m}$. Favourable initial conditions for phytoplankton growth resulted in nutrient depletion by 20 May, and to maintain further algal growth, nutrients were replenished, at their initial concentrations, on this date.

The $10 \%$ renewal rate is taken into account when increase in cell numbers etc. is given, and the instantaneous increase in mass $(N)$ of the phytoplankton in the enclosures can then be given as:

$$
\mathrm{d} N / \mathrm{d} t=\left(\mu-v V^{-1}\right) N+N_{\mathrm{B}} v V^{-1}
$$

where $\mu\left(\mathrm{d}^{-1}\right)$ is the growth rate, $V\left(\mathrm{~m}^{3}\right)$ the volume of the enclosure, $V\left(\mathrm{~m}^{3} \mathrm{~d}^{-1}\right)$ the dilution rate and $N_{\mathrm{B}}$ the supply of biomass to the enclosure from the incoming water.

Surface irradiance was measured continuously in close proximity to the enclosures, averaged every $10 \mathrm{~min}$, and recorded in a Li-Cor LI-1000 DataLogger. Other samples, profiles or measurements were taken every second day. Diffuse attenuation profiles in the enclosures were measured with a $4 \pi$ collector (Biospherical Instruments Inc.). Salinity $(\%)$ and temperature $\left({ }^{\circ} \mathrm{C}\right)$ profiles were measured (ca 09:00 h) with a salinotherm (Salinity Temperature Bridge Type M.C.5).

Analyses of nitrate, phosphate, and silicate, using a Skalar autoanalyser, were conducted on freshly collected samples. Phytoplankton identification and counting, using the sedimentation method of Utermöhl (1931), were carried out on samples preserved with neutralised formalin (final conc. $0.4 \%$ ). Species identification was made where possible: otherwise, the phytoplankton were separated into broad taxonomic categories.

Samples for particulate carbon and nitrogen analysis (50 to $100 \mathrm{ml}$ ) were filtered through precombusted glass fibre filters (Whatman GF/F) and immediately frozen. The filters were not treated with acid, and particulate carbon and nitrogen were measured in a CHN analyser. Samples for chlorophyll a (chl a) measurement $(50$ to $100 \mathrm{ml}$ ) were filtered through a Sartorius membrane filter $(0.45 \mu \mathrm{m})$, then extracted in $90 \%$ acetone overnight as described by Parsons et al. (1984), and analysed on a Turner Design Model 10-AU Fluorometer according to the new method without acidification (Welschmeyer 1994).
Photosynthesis was measured using the ${ }^{14} \mathrm{C}$ method, according to Steemann Nielsen (1952) and Gargas (1975). The samples were incubated in $100 \mathrm{ml}$ incubation bottles for $4 \mathrm{~h}$ in situ at a $2 \mathrm{~m}$ (middle) depth in the enclosures, filtered onto Sartorius membrane filters $(0.45 \mu \mathrm{m})$, frozen, and later counted in a Packard Tricarb, 1900 CA Liquid Scintillation Analyzer after fuming with $\mathrm{HCl}$. Total $\mathrm{CO}_{2}$ was calculated from $\mathrm{pH}$ and alkalinity using a more precise modification of the standard method of Parsons et al. (1984) (D. Crawford pers. comm.). Samples from the enclosures supplied with nitrate and phosphate only, in which the coccolithophorid Emiliania huxleyi bloomed, were not treated with fumed $\mathrm{HCl}$, but treated as described in Paasche \& Brubak (1994), with separation of ${ }^{14} \mathrm{C}$ in coccolith carbonate from photosynthetically assimilated ${ }^{14} \mathrm{C}$ by the microdiffusion method. The advantage of this method is that both parameters are measured in the same sample. To rule out contamination of ${ }^{14} \mathrm{C}$ in the filters, activity was measured in blank filters (triplicates) and subtracted from concentration of the intake water. Daily photosynthesis and light calcification were calculated as a function of \% daily irradiance received during the incubation period.

\section{RESULTS}

\section{Site conditions}

From the onset of the experiment on 14 May until 27 May, weather conditions were characterised by high and stable irradiance averaging $39.5 \mathrm{~mol} \mathrm{~m}^{-2} \mathrm{~d}^{-1}$ (Fig. 1). During the second half of the experiment, from 30 May through 9 June, irradiance decreased, averaging only $16.2 \mathrm{~mol} \mathrm{~m}^{-2} \mathrm{~d}^{-1}$. From being similar in all

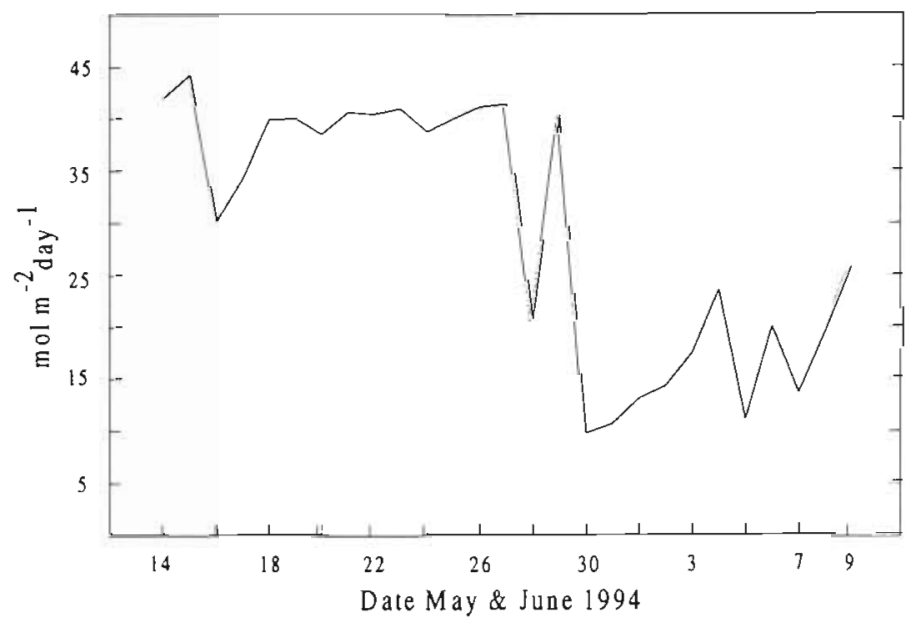

Fig. 1. Development of surface irradiance (photosynthetically active radiation, PAR) during the experimental period 14 May to 9 June 1994 


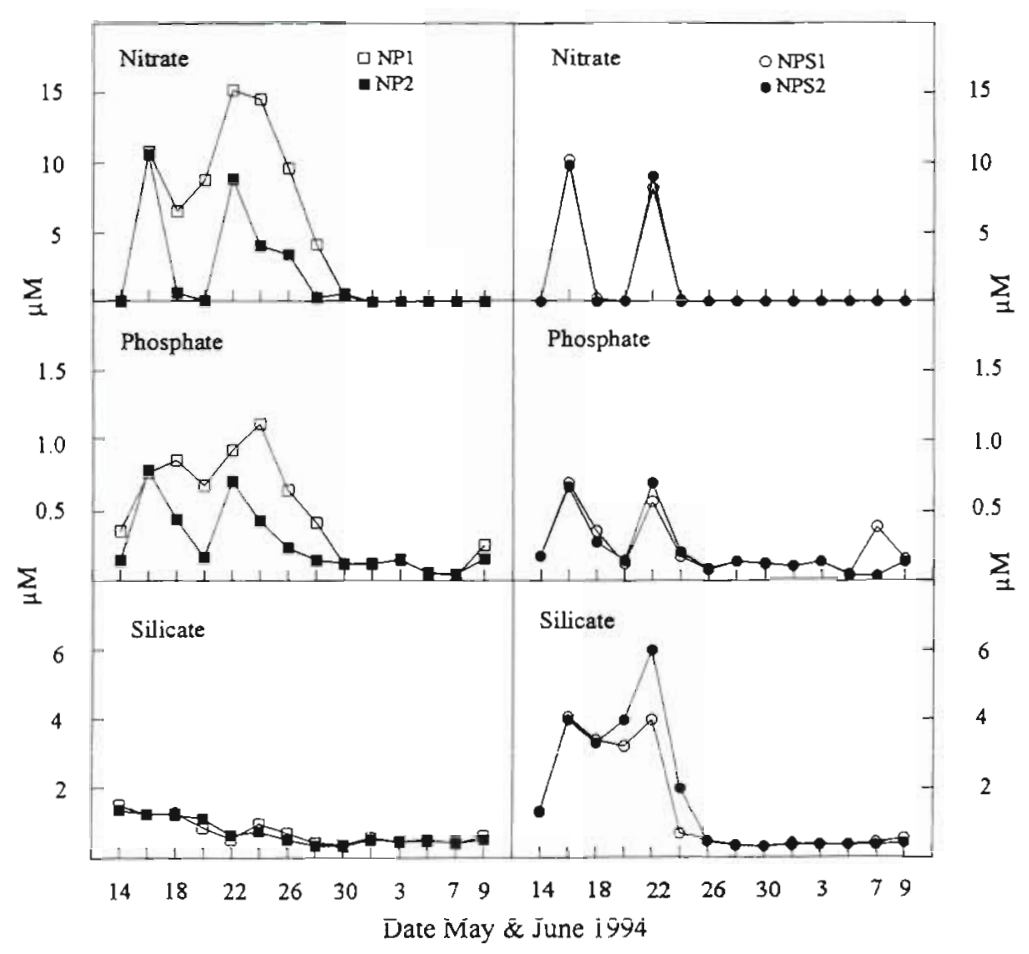

Fig. 2. Concentration of nitrate, phosphate, and silicate in enclosures NP1, NP2, NPS1, and NPS2 during the experimental period

enclosures, diffuse attenuation coefficient $\left(K_{T}\right)$ developed to lower values in the NP enclosures $\left(K_{T}=0.14\right.$ to $0.87)$ than in the NPS enclosures $\left(K_{T}=0.74\right.$ to 1.16$)$, indicating that the irradiance intensities inside the NPS enclosures were lower than in the NP enclosures throughout the experiment. Seawater temperature was $9.7^{\circ} \mathrm{C}$ at the start of the experiment, and fluctuated between 8.0 and $11.5^{\circ} \mathrm{C}$, both inside and outside the enclosures, during the experimental period. The temperature fluctuated less than $0.1^{\circ} \mathrm{C}$ among the enclosures. On a few occasions, the temperature difference between the inside and outside of the enclosures reached $0.3^{\circ} \mathrm{C}$, but was normally less. Salinity in the enclosures increased slightly during the experimental period, from 28.5 to $30.0 \%$.

\section{Nutrients}

The first nutrient samples, on 14 May, were collected before addition of nutrients took place, and therefore represent the natural concentrations in the seawater. The nutrients added on 14 May were rapidly consumed by a growing phytoplankton community (Fig. 2). The concentration of nitrate was depleted $(<0.05 \mu \mathrm{M})$ in NPS1, NPS2, and NP2, although still available in NP1, by 20 May. The replenished nutrients, added at initial concentrations on 20 May, were again rapidly consumed and depleted in NPS1 and NPS2 by 24 May. Nitrate was consumed more slowly in the NP enclosures to which silicate was not added, and again was consumed most slowly in NP1. Phosphate depletion showed a similar pattern to that of nitrate, which was not unexpected, as nitrate and phosphate were supplied in a Redfield ratio (16:1). Phosphate remained detectable, minimum concentrations of $0.05 \mu \mathrm{M}$ occurring on 5 and 7 June. Naturally occurring silicate in the NP enclosures, to which silicate was not added, decreased from its initial concentration of $1.5 \mu \mathrm{M}$, but was never depleted below $0.3 \mu \mathrm{M}$. In the NPS enclosures, to which silicate was added, concentrations higher than $3 \mu \mathrm{M}$ were observed before 22 May; following this, silicate was rapidly exhausted. From 26 May through the remainder of the experiment, concentrations of about $0.4 \mu \mathrm{M}$ were measured. In the surrounding seawater, from which the inlet water was taken, low nutrient concentrations were measured throughout the experimental period, the nitrate concentration ranging between not detectable and $1.4 \mu \mathrm{M}$, phosphate between 0.04 and $0.2 \mu \mathrm{M}$, and silicate between 0.7 and $1.3 \mu \mathrm{M}$.

\section{Phytoplankton community}

NP-fertilised enclosures

The phytoplankton community in enclosures NP1 and NP2 was initially dominated by small flagellates (Figs. $3 \& 4$ ). Phaeocystis pouchetii (single cells) was the most important species in terms of numbers with

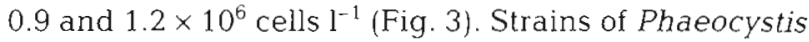
isolated from the sampling area were confirmed as $P$. pouchetii both by electron microscope and DNA sequencing analysis (L. Medlin pers. comm.). Because Phaeocystis flagellates are small ( 4 to $8 \mu \mathrm{m}$ ), their contribution to the biomass was not as high as the cell numbers suggest. Flagellate numbers were initially higher in NP2 than in NP1 but decreased in both enclosures over the course of the experiment (Fig. 4). The flagellate numbers in NP1 were stable or decreasing at the beginning of the experiment. The higher initial flagellate numbers in NP2 (Figs. 3 \& 4) and the more rapid initial growth of $P$. pouchetii can probably explain why nutrients were consumed faster in this enclosure compared to NP1. P. pouchetii decreased in 
cell numbers in both enclosures and was not seen much after 30 May (Fig. 3). The other flagellates developed according to the same pattern as $P$. pouchetii, with fewer than $0.2 \times 10^{6}$ cells $1^{-1}$ observed after 26 May (Fig. 4)

Emiliania huxleyi started to increase in cell numbers from $18 \mathrm{May}$, and reached a

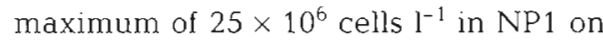
3 June and $18.5 \times 10^{6}$ cells $\mathrm{l}^{-1}$ in NP2 on 7 June (Fig. 3). The growth rate of $E$. huxleyi between 22 May and 3 June was also somewhat lower in NP2 than NP1, at 0.32 and $0.40 \mathrm{~d}^{-1}$, respectively. The $10 \%$ daily dilution due to water renewal was taken into account. When the bloom peaked, E. huxleyi constituted more than $95 \%$ of the phytoplankton community in terms of cell numbers. Decreasing numbers of E. huxleyi were observed in both NP1 and NP2 towards the end of the experimental period.

Diatom numbers, which were initially low at 0.02 and $0.2 \times 10^{6}$ cells $\mathrm{l}^{-1}$ in NP2 and NP1, respectively, reached small maximums of 1.2 and $2.6 \times 10^{6}{\text { cells } l^{-1}}^{-1}$ on 26 and 22 May, respectively (Fig. 4) The dominant species was Skeletonema costatum (Greville) Cleve. While the highest flagellate numbers were found in NP2, the highest diatom numbers were observed in NP1, which also had the highest initial total cell numbers. Dinoflagellates were scarcely represented early on, with less than $0.001 \times$ $10^{6}$ cells $\mathrm{l}^{-1}$, but numbers increased in early June to maximum concentrations of 0.10 and $0.14 \times 10^{6}$ cells $I^{-1}$ in NP1 and NP2, respectively (Fig. 4). The dominant dinoflagellates were Scrippsiella trochoidea (Stein) Lemmermann, Protoperidinium bipes Pavillard, and an unidentified group of naked dinoflagellates $(20$ to $30 \mu \mathrm{m})$. These unidentified forms dominated (>90\%) until 30 May, at which time $S$. trochoidea and $P$. bipes became dominant, and remained so for the duration of the experiment.

\section{NPS-fertilised enclosures}

As in the NP-fertilised enclosures, the initial phytoplankton community in NPS1 and NPS2 was dominated by flagellates, particularly Phaeocystis pouchetii

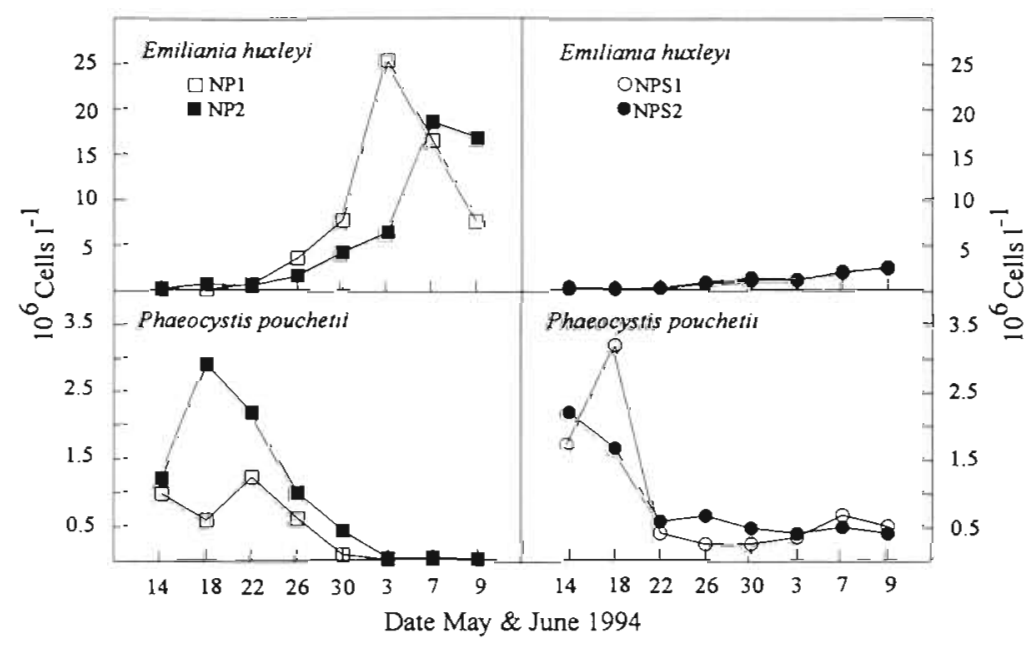

Fig. 3. Development of Emiliania huxleyi and Phaeocystis pouchetii in NP1, NP2, NPS1, and NPS2 during the experimental period

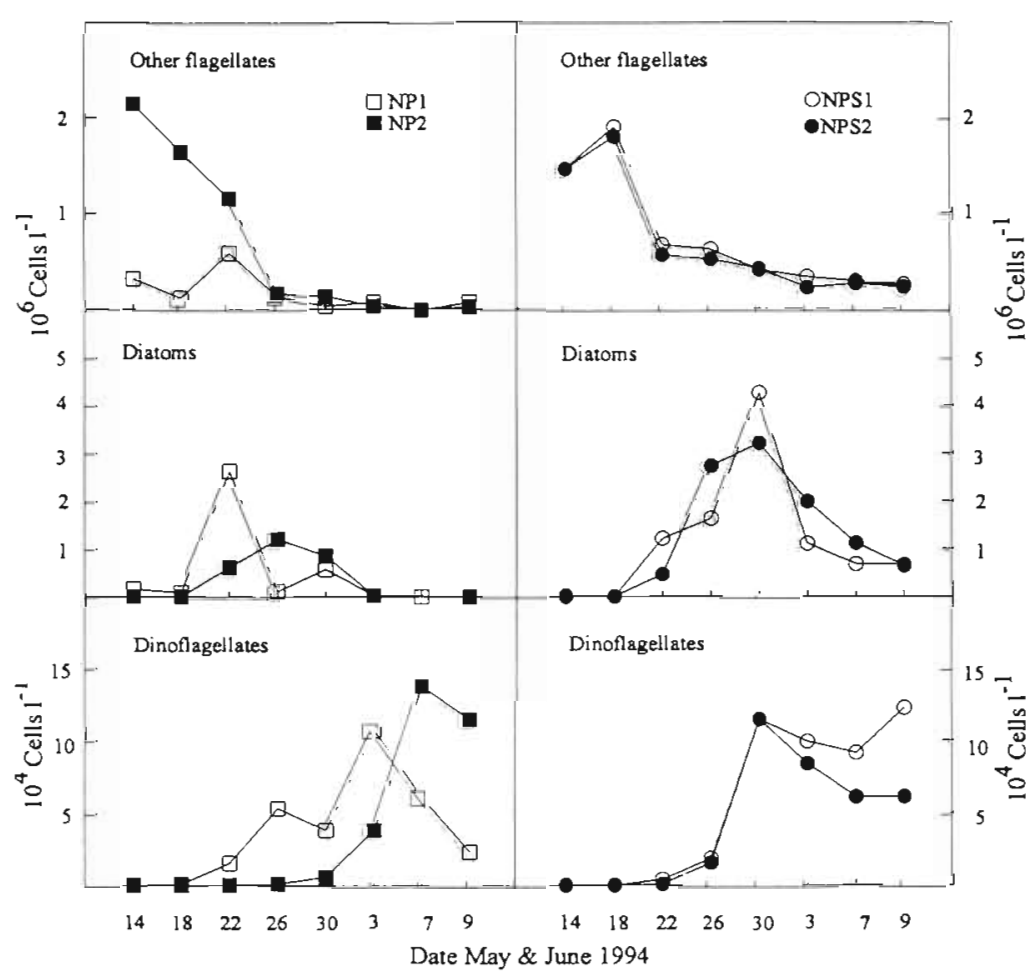

Fig. 4. Development of flagellates, diatoms and dinoflagellates in NP1, NP2, NPS1, and NPS2 during the experimental period

(Figs. 3 \& 4). The cell numbers were more similar in these 2 enclosures $\left(2.5\right.$ and $3.1 \times 10^{6}$ cells $\left.\mathrm{l}^{-1}\right) . P$. pouchetii did not subsequently decline to such low numbers as in the NP enclosures, but remained at a stable level of between 0.2 and $0.6 \times 10^{6} \mathrm{l}^{-1}$. On average, the numbers of $P$. pouchetii in the NPS enclosures were between 20 and $100 \%$ higher than those in the 
NP enclosures. The numbers of other flagellates also remained higher in the NPS enclosures than in the NP enclosures during the second half of the experiment, ranging between 0.2 and $0.6 \times 10^{6} \mathrm{I}^{-1}$ from 26 May through the remainder of the experiment.

Diatoms increased in number in both enclosures from 22 May, and on 30 May reached maxima of 4.3 and $3.2 \times 10^{6}$ cells $^{-1}$ in NPS1 and NPS2, respectively (Fig. 4). Skeletonema costatum and Pseudonitzschia $\mathrm{sp}$. were the dominant diatoms, constituting approximately 60 and $30 \%$, respectively, of the total diatom numbers. The average diatom numbers in NPS1 and NPS2 (1.2 and $1.3 \times 10^{6}$ cells $\mathrm{l}^{-1}$, respectively) were much higher than in NP1 and NP2 $\left(0.3\right.$ and $0.6 \times 10^{6}$

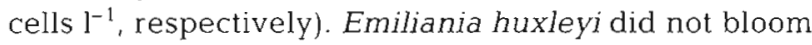
in the NPS enclosures, in contrast to the NP enclosures, but occurred in cell numbers $\left(<2.4 \times 10^{6}\right.$ cells $\left.\mathrm{I}^{-1}\right) 1$ order of magnitude lower than in the NP enclosures throughout the entire experiment (Fig. 3). The dinoflagellates were, as in the NP enclosures, scarcely represented until 30 May. They then reached a maximum of $12 \times 10^{4}$ cells I$^{-1}$ (Fig. 4). The dinoflagellate community consisted mainiy of Protoperiainium bipes and Scrippsiella trochoidea.

The surrounding seawater was characterised by low cell numbers throughout the entire experiment, although numbers of Emiliania huxleyi did increase somewhat. From an initial concentration of $0.05 \times 10^{6}$ cells $\mathrm{l}^{-1}$ a maximum concentration of $2.3 \times$ $10^{6}$ cells $\mathrm{I}^{-1}$ was reached on 3 June. Diatoms were observed in concentrations between 0.1 and $0.6 \times 10^{6}$ cells $\mathrm{l}^{-1}$, Phaeocystis pouchetii between 0.2 and $0.9 \times 10^{6}$ cells $\mathrm{l}^{-1}$, and other flagellates between 0.1 and $1.5 \times 10^{6}$ cells $l^{-1}$.

The main divergence in the phytoplankton community development between the 2 different treatments was the occurrence of much stronger blooms of Emiliania huxleyi in enclosures supplied only with nitrate and phosphate (NP1 and NP2). The opposite was true of diatoms, which were dominant in the NPS1 and NPS2 enclosures.

\section{Particulate carbon and nitrogen}

A weak increase in particulate nitrogen was observed in the NP enclosures from 24 May (Fig. 5). In the NPS enclosures, the concentration of particulate nitrogen also increased weakly from late May, but then decreased from the end of May until the end of the experimental period. The peak in particulate nitrogen in the NPS enclosures correlated strongly with the peak in diatom abundance. The average amount of particulate nitrogen $(105,108,124$, and $121 \mathrm{mg} \mathrm{m}^{-3}$ in NP1, NP2, NPS1, and NPS2, respectively) indicated higher accumulations of particulate nitrogen in the silicate-supplied enclosures where diatoms dominated. The pattern of particulate carbon was similar to that of nitrogen, although more carbon compared to nitrogen was accumulated during the experiment in the NP enclosures (Fig. 5). The divergent development of particulate nitrogen and carbon between the 2 treatments can be seen even more clearly in the atomic ratio of $\mathrm{C}: \mathrm{N}$ (Fig 5). While the $\mathrm{C}: \mathrm{N}$ ratio increased by a factor of 3 from 18 May to the end of the experiment in Emiliania huxleyi-dominated (NP) enclosures, the $C: N$ ratios were more stable, in general ranging between 5 and 10 , in the diatom-dominated (NPS) enclosures. Since these sam-

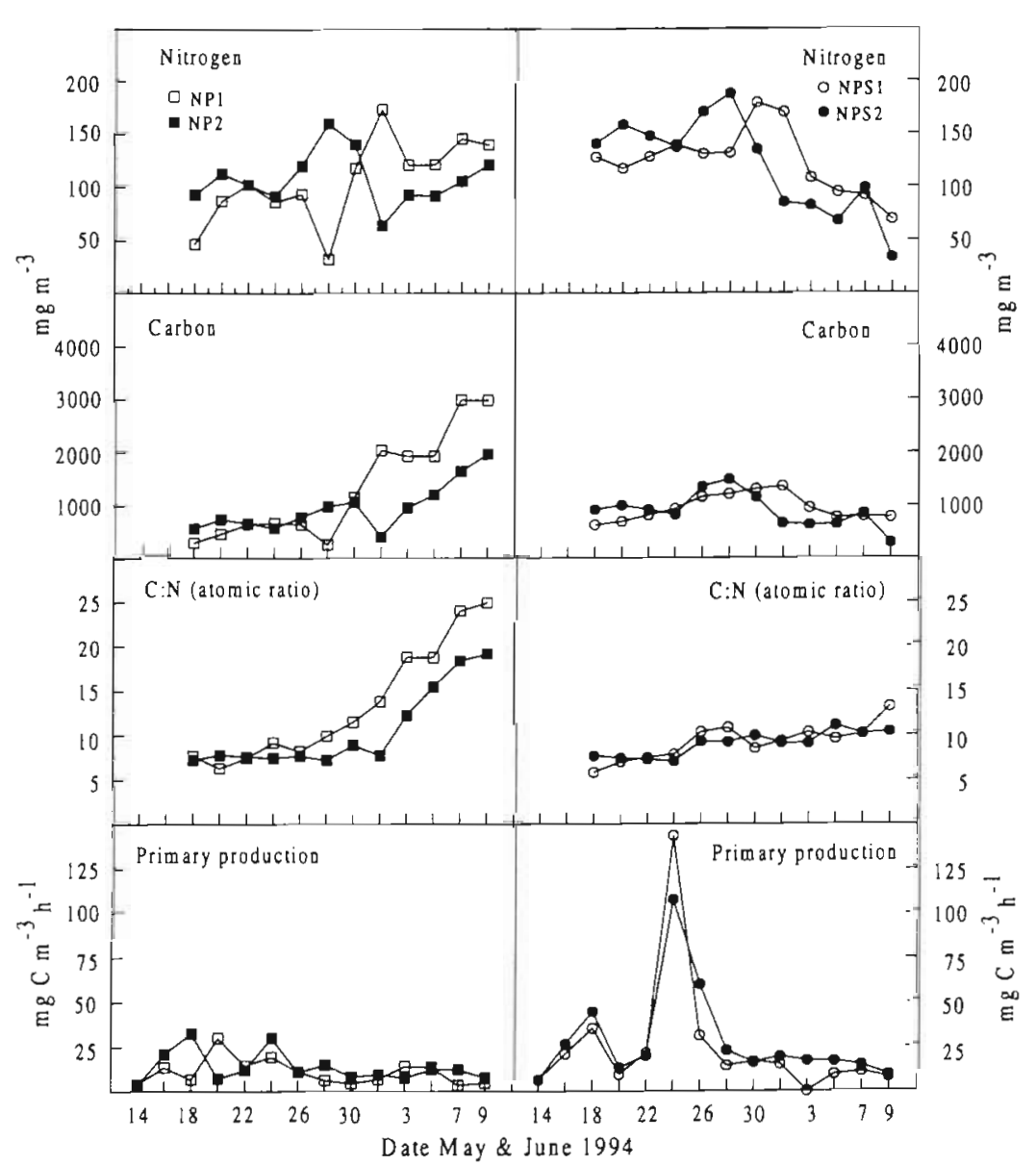

Fig. 5. Development of particulate nitrogen and carbon, atomic C:N ratio, and rate of photosynthetic assimilation of carbon 
ples were not treated with acid, the particulate carbon here included both inorganic and organic carbon.

\section{Photosynthesis and calcification}

The photosynthetic rate increased from 14 May to 18 May in NP2, NPS1 and NPS2 (Fig. 5). Its subsequent decrease in these 3 enclosures between 18 and 20 May was probably due to nutrient limitation, as nitrate was nearly depleted during this period. A similar pattern did not occur in NP1, but here nutrients were still in excess on these dates. After the replenishment of nutrients on 20 May, a second peak in primary production

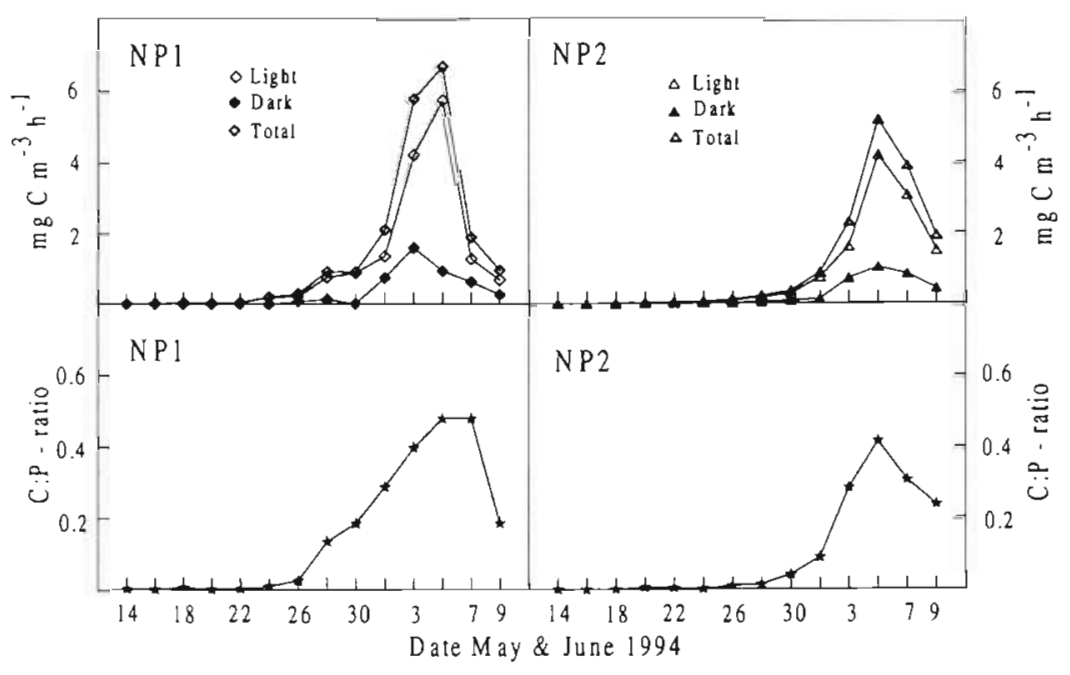

Fig. 6. Calcification rate in enclosures NP1 and NP2, and the ratio between calcification and photosynthesis $(\mathrm{C}: \mathrm{P})$ was observed in the NPS enclosures. During this period, diatoms increased most rapidly in numbers. A similar rapid increase in primary production was not observed in the NP enclosures, which were not supplied with silicate, and here the numbers of diatoms were decreasing around 24 May. Integrated over the experimental period, carbon production was 2-fold higher in the NPS enclosures $\left(6.1\right.$ and $7.0 \mathrm{~g} \mathrm{~m}^{-3}$ ) compared to the NP enclosures (2.6 and $3.2 \mathrm{~g} \mathrm{~m}^{-3}$ ) (Table 1). The difference was due mainly to the very high photosynthetic rate observed in the NPS enclosures around 24 May when diatoms peaked, while biomass (measured as chl a) was quite similar in all 4 enclosures, averaging between 6.1 and $6.9 \mathrm{mg} \mathrm{m}^{-3}$ during the experimental period. In contrast, the average concentration in the surrounding seawater was $1.9 \mathrm{mg} \mathrm{m}^{-3}$.

It has previously been reported that blooms of Emiliania huxleyi occur more abundantly in enclosures supplied only with nitrate and phosphate (Egge 1993, Egge \& Heimdal 1994). Calcification was therefore measured only in the NP enclosures. The rate of calci-

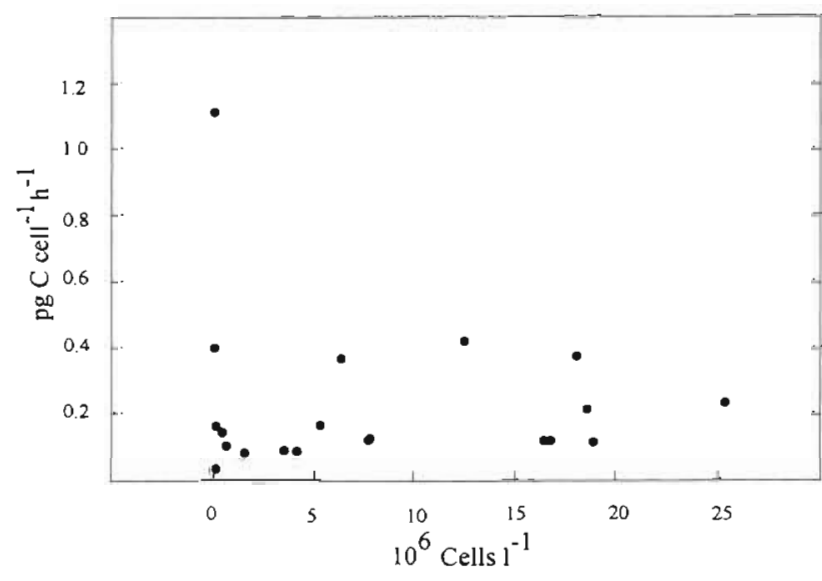

Fig. 7 Calcification rate per cell as a function of Emiliania huxleyı numbers

fication increased from 22 May and reached a maximum on 5 June in both enclosures, with rates of 6.7 and $5.2 \mathrm{mg} \mathrm{C} \mathrm{m} \mathrm{m}^{-3} \mathrm{~h}^{-1}$ in NP1 and NP2,

Table 1 Nutrient consumption $\left(\mathrm{g} \mathrm{m}^{-3}\right)$, carbon production $\left(\mathrm{g} \mathrm{m}^{-3}\right)$ and the ratio between produced carbon and consumed nutrient for each of the enclosures (NP1, NP2, NPS1, and NPS2), mean of each treatment (NP and NPS) and the difference between the 2 treatments (NPS-NP). Integrations are made over the entire experimental period

\begin{tabular}{|lrrrrrrr|}
\hline & NP1 & NP2 & NP & NPS1 & NPS2 & NPS NPS - NP \\
\hline N consumed & 0.5 & 0.6 & 0.6 & 0.6 & 0.6 & 0.6 & 0.0 \\
P consumed & 0.1 & 0.1 & 0.1 & 0.1 & 0.1 & 0.1 & 0.0 \\
Si consumed & 0.1 & 0.1 & 0.1 & 0.6 & 0.5 & 0.6 & 0.5 \\
C produced & 2.6 & 3.2 & 2.9 & 6.1 & 7.0 & 6.6 & 3.7 \\
C prod.:N cons. & 5.8 & 5.7 & 5.8 & 10.3 & 12.1 & 11.2 & \\
C prod:.P cons. & 28.9 & 29.1 & 29.0 & 55.4 & 58.4 & 56.9 & \\
& & & & & & & \\
\hline
\end{tabular}
respectively (Fig, 6). Calcification showed the same pattern in both darkness and light, but dark calcification was always much lower, ranging between 16 and $50 \%$ (averaging 30\%) of light calcification. The ratio of calcification to photosynthesis (C:P) increased with cell numbers of E. huxleyi, reaching a maximum of 0.48 in NP1 and 0.42 in NP2 on 5 and 7 June. The sum of light and dark calcification is used here for comparison with photosynthesis. The rate of calcification per cell in general ranged between 0.1 and 
$0.4 \mathrm{pg} \mathrm{C}$ cell $^{-1} \mathrm{~h}^{-1}$ (Fig. 7). Integrated over the experimental period 0.5 and $0.3 \mathrm{~g} \mathrm{C} \mathrm{m}^{-3}$ was tied up by calcification in NP1 and NP2, respectively.

Equal amounts of nitrate and phosphate were supplied to all enclosures during the experimental period, and so the consumption of these nutrients was also equal (Table 1). A 2-fold higher integrated production of carbon was observed in the NPS enclosures as compared to the NP enclosures. This indicates a more efficient use of nutrients in these enclosures. In the NPS enclosures $0.5 \mathrm{~g} \mathrm{~m}^{-3}$ more silicate was consumed than in the NP enclosures, while the difference in carbon production between the 2 treatments was $3.7 \mathrm{~g} \mathrm{~m}^{-3}$. Thus, it indicates that for each $g$ silicate added, the carbon production was increased by $7.4 \mathrm{~g}$

\section{DISCUSSION}

\section{Species composition}

The clearest outcome of this experiment was the deveiopment of contrasting phytopiankion communities as a result of the different nutrient treatments. whether diatoms or coccolithophorids bloomed was determined by the presence or absence, respectively, of silicate. The occurrence of Emiliania huxleyi blooms in the NP enclosures confirmed observations from previous mesocosm experiments, in which this species bloomed in 16 of 25 enclosures fertilised only with nitrate and phosphate (Egge 1993, Egge \& Heimdal 1994). Natural blooms of E. huxleyi, some lasting for more than a month (author's pers. obs.) occurred simultaneously in several fjords on the west coast of Norway. The maximum density of $E$. huxleyi in the seawater outside the enclosures ( 2 to $3 \times 10^{6} \mathrm{I}^{-1}$ on 3 June) was much lower than those found in the NP enclosures, but similar to those in the NPS enclosures. When silicate was made available, however, the coccolithophorid E. huxleyi could not compete with diatoms. Officer \& Ryther (1980) suggest that addition of silicate to eutrophic regions, where nitrogen and phosphate are in excess, may change a flagellate-dominated population to a diatom-dominated population. Elsewhere diatoms have been observed to dominate in enclosure experiments when the concentration of silicate was $>2 \mu \mathrm{M}$ (Egge \& Aksnes 1992), or when the N:Si ratio was low (Schöllhorn \& Granéli 1996). In the present study, the silicate concentration was found to be higher than $2 \mu \mathrm{M}$ in NPS1 and NPS2 only before 24 May, which was $6 \mathrm{~d}$ before the diatom bloom peaked. Nitrate was also depleted from this date in the NPS enclosures. Situations in which nutrients become depleted but the phytoplankton continue to grow for several days have been observed several times in pre- vious experiments (Egge 1993, Egge \& Heimdal 1994). Although nutrients are undetectable it does not mean that they are not available for the phytoplankton. A supply of, for instance, $3 \mu \mathrm{M}$ nitrate $\left(=42 \mu \mathrm{g} \mathrm{N}^{-1}\right)$, which in this experiment was added every second day, will be enough to support production of $4.2 \times 10^{6}$ cells $\mathrm{l}^{-1}$ with a nitrate content of $10 \mathrm{pg} \mathrm{cell}^{-1}$. The observed increase will, however, be lower because of dilution.

\section{Phaeocystis pouchetii}

The observation that Phaeocystis pouchetii and other flagellate populations disappeared from NP1 and NP2, yet remained stable (between 0.2 and $0.6 \times 10^{6}$ cells l-1 $^{-1}$ ) in NPS1 and NPS2, deserves further comment. Various growth strategies have been suggested for Phaeocystis (Veldhuis et al. 1991). P. pouchetii has been shown to be more successful (reach higher cell concentrations) when the concentrations of nutrients, especially phosphate, are high (Egge \& Heimdal 1994). A high halfsaturation constant $\left(K_{s}\right)$ for both phosphate and nitrate ( 3 and 4 Hivi, respeciiveiyj indicates iow uptake af́rinity for these nutrients (Lancelot et al. 1986, Veldhuis et al. 1991). Differences in nutrient supply cannot explain the difference in cell density in the present experiment, however, because all 4 enclosures were initially supplied with the same concentrations of nitrate and phosphate. Moreover, these nutrients were depleted in NPS1 before the NP enclosures (Fig. 2). P. pouchetii may, however, have a small silicate requirement as $\mathrm{X}$-ray microanalysis has showed silicate-containing structures (K. M. Fagerbakke pers. comm.). Blooms of Phaeocystis often succeed blooms of diatoms in the North Sea (Gieskes \& Kraay 1977, Cadée \& Hegemann 1986, Veldhuis et al. 1986), suggesting that organic substances released by decaying diatom populations might either trigger growth of, or nutritionally sustain, P. pouchetii (Weisse et al. 1986). In the case of phosphorus, however, both Emiliania huxleyi and Phaeocystis colonies are able to utilise organic phosphate after its hydrolysis by phosphatases, so the availability of organic phosphorus components should not give a particular advantage to Phaeocystis (Kuenzler \& Perras 1965, Veldhuis et al. 1991).

Irradiance may also have affected the difference in Phaeocystis pouchetii density between the NP- and NPS enclosures. A lower diffuse attenuation $\left(K_{T}=0.14\right.$ to 0.87 ) in the NP enclosures compared to the NPS enclosures $\left(K_{T}=0.74\right.$ to 1.16$)$ showed that the irradiances within the NPS enclosures were lower than in the NP enclosures. This could suggest that $P$. pouchetii has a competitive advantage when irradiance is low, in agreement with earlier experiments demonstrating Emiliania huxleyi dominance when incident irradiance 
was high $\left(>20 \mu \mathrm{mol} \mathrm{m}^{-2} \mathrm{l}^{-1}\right)$, and $P$. pouchetii dominance in NP enclosures when irradiance intensities decreased (Egge 1993, Jacobsen et al. 1995). A combination of silicate depletion (after 24 May) and low irradiance intensities may have allowed diatoms and $P$. pouchetii to coexist in the NPS enclosures in the present experiment.

One other explanation for the disappearance of Phaeocystis pouchetii from the NP enclosures might be the presence of Emiliania huxleyi. In several other experiments, number of other species have decreased when E. huxleyi numbers have increased (author's pers. obs.), suggesting a possible incompatibility with E. huxleyi. This may explain the reduction in $P$. pouchetii population densities in the NP enclosures in spite of reduced irradiation, which evidence suggests may be advantageous to $P$. pouchetii, and should reduce the growth of $E$. huxleyi. The lower number of flagellates seen in these experiments may also indicate incompatibility between $E$. huxleyi and other species.

\section{Carbon production and accumulation}

Given that equal amounts of nitrate and phosphate were supplied to all the enclosures, and these nutrients were consumed, one might expect an equivalent biomass to be produced in all enclosures Perhaps one could expect a higher chl a biomass in the diatomdominated enclosures, as diatoms usually have a higher chla:carbon ratio (Langdon 1988). However, the chl a biomass was very similar in all the enclosures, ranging, on average, from 6.1 to $6.9 \mathrm{mg} \mathrm{m}^{-3}$. Carbon productions integrated over the whole period were, however, twice as high in the NPS enclosures as in the NP enclosures. The additional supply of silicate changed the phytoplankton community towards diatom dominance, and this community is apparently more efficient at producing carbon than the flagellatedominated community in the NP enclosures. In the present experiment the difference between Si supply and no Si supply corresponds to $7.4 \mathrm{~g} \mathrm{C}$ for each $\mathrm{g}$ silicate consumed. Results from other enclosures gives nearly identical values: for each $g$ silicate consumed $6.9 \mathrm{~g}$ carbon was produced (Wassmann et al. unpubl.) The latter values refer to an experiment carried out during the same period of time, but in deeper enclosures $(10 \mathrm{~m})$ where vertical flux of particulate biogenic matter was measured. More silicate was available in these enclosures and photosynthetic rates were measured at 3 depths.

Although production was higher in the NPS enclosures it is not reflected in the accumulation of particulate carbon (Fig. 5). The average amount of particulate carbon was quite similar in NPS1, NPS2, and NP2, ranging from 906 to $974 \mathrm{mg} \mathrm{m}^{-3}$. The average amount of particulate carbon was, however, somewhat higher in NP1 (1345 $\left.\mathrm{mg} \mathrm{m}^{-3}\right)$, in which the highest concentration of Emiliania huxleyi was found. The contribution from calcification (estimated at 0.5 and $0.3 \mathrm{~g} \mathrm{C} \mathrm{m}^{-3}$ in NP1 and NP2, respectively) cannot by itself explain this similarity in amount of particulate carbon.

The discrepancy between the relative high production and low accumulation of particulate carbon in the NPS enclosures, may be explained by a higher loss rate in these enclosures compared to the NP enclosures. Several loss factors, such as grazing, lysis and dissolution, and sedimentation, all of which are important in phytoplankton bloom dynamics, could have reduced the standing stock of particulate carbon (Brussaard et al. 1995).

\section{Loss factors}

Micro- and mesozooplankton grazing can control the development and succession of phytoplankton either directly, through general or selective grazing, or indirectly, by mesozooplankton grazing on microzooplankton (Frost 1991, Riegmann et al. 1993). Grazing experiments, conducted in NP1 only, showed that the increase and peak of diatoms dominated by Skeletonema costatum (Fig. 4) stimulated growth of microzooplankton, and the diatoms became grazer controlled (Nejstgaard et al. 1997). An estimated 65 to $80 \%$ of the standing stock of algae was removed daily when ciliate numbers were highest. In contrast, Emiliania huxleyi did not stimulate growth of protozoans, but escaped grazing control and was able to produce nearly monospecific blooms. Grazing pressure from copepods was about 1 order of magnitude lower than that from microzooplankton, and ingestion rates were similar during blooms of diatoms and flagellates.

Lower accumulation of particulate carbon than expected from production data may also have been caused by lysis and dissolution of cells by bacteria or viruses. Lysis of phytoplankton has been reported, and virus-like particles have been found in all major algal classes (Reynolds et al. 1982, Van Etten et al. 1991, Bratbak et al. 1993). It may therefore be possible that viruses may have caused phytoplankton lysis in the present experiment, but there is no information which suggests that diatoms in the NPS enclosures were particularly exposed. On the contrary, van Boekel et al. (1992) found no increase in lysis rate at the end of the diatom spring bloom.

A strong peak in the primary production rate, as observed in the NPS enclosures, may have resulted in a higher rate of sedimentation than that for the more stable production in the NP enclosures. Except for the 
lower $0.5 \mathrm{~m}$ these enclosures were stirred, but some sedimentation of a small amount of the phytoplankton might have occurred. Because of the stirring, which was achieved in order to get samples as representative as possible of the water column, sedimentation could not be measured in these enclosures. Stirring, in addition to keeping the water column homogeneous, can also have influenced the formation of phytoplankton aggregates and therefore sedimentation (Kiørboe et al. 1994). The encounter rate between phytoplankton cells increases, and especially diatoms form aggregates because of the high stickiness and become a major component of sedimented cells (Wassmann 1991, Kiørboe et al. 1994). In 2 additional enclosures, $10 \mathrm{~m}$ deep and stirred in the upper $4 \mathrm{~m}$ only, sedimentation rates were measured with sediment traps in the bottom. The 2 long enclosures were designed to investigate the effects of silicate on vertical export of phytoplankton material, both of which were fertilised with nitrate and phosphate, and one of which was additionally treated with silicate (Wassmann et al. unpubl.). The results of that experiment show, as already mentioned, that for each $g$ siìcate added the production increased with $6.9 \mathrm{~g}$ carbon, and in addition the vertical flux was enhanced by $3.6 \mathrm{~g}$ carbon.

\section{Calcification}

Particulate carbon measurements in the present experiment include inorganic carbon components which can be relatively high in the NP enclosures because of coccoliths (Fig. 5). Calcification integrated during the entire experimental period corresponds to 0.5 and $0.3 \mathrm{~g} \mathrm{C} \mathrm{m}^{-3}$ in NP1 and NP2, respectively. Even with the contribution from calcification added to photosynthetic production (Table 1), one still cannot explain why more particulate carbon accumulates in the NP enclosures during the experiment compared to the NPS enclosures. The microdiffusion method has previously mainly been used on cultures, and only on a few occasions in field (Paasche \& Brubak 1994, Skattebøl 1995). The calcification per cell measured in the present experiment $\left(0.1\right.$ to $\left.0.4 \mathrm{pg} \mathrm{C} \mathrm{cell}^{-1} \mathrm{~h}^{-1}\right)$ is in agreement with the results of Paasch \& Brubak (1994), who reported irradiance-saturated calcification in cultures at $0.3 \mathrm{pg} \mathrm{C}$ cell $^{-1} \mathrm{~h}^{-1}$ in a short ( $2 \mathrm{~h}$ ) incubation experiment. The real rate may have been even higher (20 to $30 \%$ ), as the calculated production based on the increase in carbon content became $0.4 \mathrm{pg} \mathrm{C} \mathrm{cell}^{-1} \mathrm{~h}^{-1}$, the same maximal rate as was measured by Balch et al. (1992). Maximum calcification rates of $0.12 \mathrm{pg} \mathrm{C}$ cell $^{-1}$ $\mathrm{h}^{-1}$, which is comparable to the lower end of our calcification rate range, have been recorded in a natural bloom (Skattebøl 1995).
A maximum C:P ratio of 0.4 to 0.5 measured when Emiliania huxleyi made up more than $95 \%$ of the cell numbers seems realistic, although several laboratory studies using pure cultures have reported a molar ratio on the order of $1: 1$ between calcification and photosynthesis (Paasche 1964, Nimer \& Merrett 1993, Paasche \& Brubak 1994). From a bloom in the Northeast Atlantic Ocean, calcification reportedly never represented more than $20 \%$ of the total carbon incorporation (Fernández et al. 1993). Skattebøl (1995) measured calcification by the microdiffusion method several times during a natural bloom of E. huxleyi, and reported a C:P ratio of 0.15 to 0.22 , however, only calcification during light was measured. We therefore conclude that the rate of calcification and the ratio between calcification and photosynthesis are comparable to those reported by other investigators and the contribution to carbon by calcification is realistic. This method is well suited for field investigations.

It is more likely that the low accumulation of particulate carbon in the silicate-treated NPS enclosures was due to a high loss rate, as the production was much nigner. The ioss factors, grazing and sedimentation, both affect diatom communities more than coccolithophorid communities. The effects of different nutrient supplies were therefore not straightforward. Treatment with nitrate, phosphate, and silicate resulted in the most productive population, the diatoms, which also had the highest loss. Treatment with nitrate and phosphate only resulted in a less productive coccolithophorid bloom. Due to low loss, however, more particulate carbon accumulated during that bloom.

Acknowledgements. We thank Mette Hordnes for nutrient analysis, Stine Skattebol for assistance with calcification analysis, and David Crawford for $\mathrm{TCO}_{2}$ data and for valuable comments on a previous version of this paper. We also thank Toby Tyrrell and 3 unknown referees for comments. This experiment was funded by the MAST II EHUX project, contract number MAS2-CT92-0038. This is EHUX contribution no. 63 .

\section{LITERATURE CITED}

Balch WM, Holligan PM, Kilpatrick KA (1992) Calcification, photosynthesis and growth of the bloom-forming coccolithophore, Emiliania huxleyi. Cont Shelf Res 12:1353-1374

Balch WB, Kilpatrick K, Holligan PM, Cucci T (1993) Coccolith production and detachment by Emiliania huxleyi (Prymnesiophyceae). J Phycol 29:566-575

Bleijswijk JDL van, Kempers ES, Wal P van der, Westbroek $P$, Egge JK, Lukk T (1994) Standing stocks of PIC, POC, PON and Emiliania huxleyi coccospheres and liths in seawater enclosures with different phosphate loading. Sarsia 79 . 307-318

Bratbak G, Egge JK, Heldal H (1993) Viral mortality of the marine alga Emiliania huxleyi (Haptophyceae) and termination of algal blooms. Mar Ecol Prog Ser 93:39-48 
Brussaard CPD, Riegman R, Noordeloos AAM, Cadée GC Witte H, Kop AJ, Nieuwland G, van Duyl FC, Bak RPM (1995) Effects of grazing, sedimentation and phytoplank ton cell lysis on the structure of a coastal pelagic foodweb. Mar Ecol Prog Ser 123:259-271.

Cadée GC, Hegemann J (1986) Seasonal and annual varıation in Phaeocystıs pouchetii (Haptophyceae) in westernmost inlet of the Wadden Sea during the 1973 to 1985 period. Neth J Sea Res 20:29-36

Cota GF, Smith WO Jr, Mitchell BG (1994) Photosynthesis of Phaeocystis in the Greenland Sea. Limnol Oceanogr 39: $948-953$

Dong LF, Nimer NA, Okus E, Merrett MJ (1993) Dissolved inorganic carbon utilization in relation to calcite production in Emiliania huxleyi (Lohmann) Kampter. New Phytol 123:679-684

Egge JK (1993) Nutrient control of phytoplankton growth: effects of macronutrients composition (N, P, Si) on species succession. Dr Scient thesis, University of Bergen

Egge JK, Aksnes DL (1992) Silicate as regulating nutrient in phytoplankton competition. Mar Ecol Prog Ser 83:281-289

Egge JK, Heimdal BR (1994) Bloom of phytoplankton including Emiliania huxleyi (Haptophyta). Effects of nutrient supply in different $N$ :P ratios. Sarsia 79:333-348

Eilertsen HC, Schei B. Taasen JP (1981) lnvestıgatıons on the phytoplankton community of Balsfjorden, Northern Norway. The phytoplankton 1976-1978. Abundance, species composition, and succession. Sarsia 66:129-141

Fernández E, Balch WM, Marañon E, Holligan PM (1994) High rates of lipid biosynthesis in culture, mesocosm and coastal populations of the coccolithophore Emiliania huxley1. Mar Ecol Prog Ser 114:13-22

Fernandez E, Boyd P, Holligan PM. Harbour DS (1993) Production of organic and inorganic carbon with a large scale coccolithophore bloom in the North-East Atlantic Ocean. Mar Ecol Prog Ser 97:271-285

Frost BW (1991) The role of grazing in nutnent-rich areas of the open ocean. Limnol Oceanogr 36:1616-1630

Gargas E (1975) A manual for phytoplankton primary production studies in the Baltic. The Baltic Marine Biologists, Publication No. 2. The Danish Agency of Environmental Protection, p 88

Gieskes WW, Kraay GW (1977) Continuous plankton records changes in the plankton of the North Sea and its eutrophic Southern Bight from 1948 to 1975. Neth J Sea Res 9 $166-196$

Heimdal BR, Egge JK, Veldhuis MJW, Westbroek P (1994) The Norwegian Emiliania huxleyi experiment. An overview. Sarsia 79:285-425

Jacobsen A, Egge JK, Heimdal BR (1995) Effects of increased concentration of nitrate and phosphate during a springbloom experiment in mesocosm. J Exp Mar Biol Ecol 187 . $239-251$

Kırrboe T, Lundgaard C, Olesen M, Hansen JLS (1994) Aggregation and sedimentation processes during a spring phytoplankton bloom: a field experiment to test coagulation theory. J Mar Res 52:297-323

Kuenzler EJ, Perras JP (1965) Phosphatases of marine algae Biol Bull (Woods Hole) 128:271-284

Lancelot C, Mathot S, Owens NJP (1986) Modelling protein synthesis, a step to an accurate estimate of net primary production: Phaeocystis pouchetii colonies in Belgian coastal waters. Mar Ecol Prog Ser 32:193-202

Langdon C (1988) On the causes of interspecific differences in the growth-irradiance relation for phytoplankton. Il. A general review. J Plankton Res 10:1291-1312

Levasseur M, Michaud S, Egge JK, Cantin G, Nejstgaard JC,
Sanders R, Fernández E, Solberg PT, Heimdal BR, Gosslin $M$ (1996) Production of DMSP and DMS during a mesocosm study of an Emiliania huxicri bloom: influence of bactereria and Calanus finmarticus grazing. Mar Biol 126 : $609-618$

Nejstgaard JC, Gismarvik 1, Solberg PT (1997) Feeding and reproduction by Calanus finmarchicus and microzooplankton grazing during mesocosm blooms of diatoms and the coccolithophore Emiliania huxleyi. Mar Ecol Prog Ser $147: 197-217$

Nimer NA, Merrett MJ (1992) Calclfication and utilization of inorganic carbon by the coccolithophorid Emilania huxleyi Lohmann. New Phytol 121:173-177

Nimer NA, Merrett MJ (1993) Calcification rate in Emillania huxleyi Lohmann in response to light, nitrate and availability of inorganic carbon. New Phytol 123:673-677

Officer CB, Ryther JH (1980) The possible importance of silicon in marine eutrophication. Mar Ecol Prog Ser 3:83-91

Paasche E (1964) A tracer study of the inorganic carbon uptake during coccolith formation and photosynthesis in the coccolithophorid Coccolithus huxleyi. Physiol Plant Suppl 3:1-82

Paasche E (1965) The effect of 3-(p-chlorophenyl)-1,1dimethylurea (CMU) on phothosynthesis and light-dependant coccolith formation in Coccolithus huxleyi. Physiol Plant 19:271-278

Paasche E, Brubak S (1994) Enhanced calcification in the coccolithophorid Emiliania huxleyi (Haptophyceae) under phosphorus limitation. Phycologia 33:324-330

Parsons TR, Maita Y, Lalli CM (1984) A manual of chemical and biological methods for seawater analysis. Pergamon Press, Oxford

Redfield AC, Ketchum BH, Richards FA (1963) The influence of organisms on the composition of seawater. In: Hill MN (ed) The sea, Vol 2. Interscience, New York, p 26-77

Reynolds CS, Thompson JM, Ferguson AJD, Wiseman SW (1982) Loss processes in the population dynamics of phytoplankton maintained in closed systems. J Plankton Res 4: $561-600$

Riegmann R, Kuipers BR, Noordeloos AAM, Witte HJ (1993) Size-differential control of phytoplankton and structure of plankton communities. Neth J Sea Res 31:255-265

Rydningen $H$ (1996) Influence on carbon chemistry by primary producers. Cand Scient thesis, University of Bergen

Rykkelid $\varnothing$ (1994) Vaaroppblomstringseksperiment $j$ poser. Effekter på planteplanktonsamfunn ved gjødsling med nitrat og silikat. Cand Scient thesis, University of Bergen

Schöllhorn E, Granéli E (1996) Influence of different nitrogen to silica ratios and artificial mixing on the structure of a summer phytoplankton community from the Swedish west coast (Gullmar Fjord). J Sea Res 35:159-167

Sikes CS, Roer RD, Wilbur KM (1980) Photosynthesis and coccolith formation: inorganic carbon sources and net inorganic reaction of deposition. Limnol Oceanogr 25:248-261

Skattebøl S (1995) Coccolithdannelse i lys og i morke hos Emiliania huxleyi (Lohmann) Hay et Mohler Laboratorie og feltundersøkelser. Cand Scient thesis, University of Oslo

Steemann Nielsen E (1952) The use of radioactive $\left({ }^{14} \mathrm{C}\right)$ for measuring organic production in the sea. J Cons Int Explor Mer 18:117-140

Stefánsson U, Richards FA (1963) Processes contributing to the nutrient distributions off the Columbia river and strait of Juan de Fuca. Limnol Oceanogr 8:394-410

Utermöhl H (1931) Neue Wege in der quantitativen Erfassung des Planktons (Mit besonderer Berücksichtigung des Ultraplanktons). Verh Int Verein Theor Angew Limnol 5: $567-596$ 
van Boekel WHM, Hansen FC, Riegman R, Bak RPM (1992) Lysis-induced decline of a Phaeocystis spring bloom and coupling with the microbial foodweb. Mar Ecol Prog Ser 81:269-276

Van Etten JL, Xia DE, Meints RH (1983) Growth cycle of a virus, $\mathrm{PBC}-1$, that infects Chlorella-like algae. Virology 126:117-125

Veldhuis MJW, Colijn F, Admiral W (1991) Phosphate utilization in Phaeocystis pouchetii (Haptophyceae). Mar Ecol 12:53-62

Veldhuis MJW, Colyn F, Venekamp AH (1986) The spring bloom of Phaeocystis (Haptophyceae) in Dutch coastal water. Neth J Sea Res 20:37-48

Wal $P$ van der, van Bleijswijk JDL, Egge JK (1994) Primary productivity and calcification rate in blooms of the cocco-

This article was submitted to the editor lithorid Emiliania huxleyi (Lohmann) Hay et Mohler developing in mesocosm. Sarsia 79:409-416

Wang-Andersen J (1996) Fettsyre- og fettalkoholsammensetninggen i marine copepoder. Cand Scient thesis, University of Bergen

Wassmann P (1991) Dynamics of primary production and sedimentation in shallow fjords and polls of western Norway. Oceanogr Mar Biol Annu Rev 29:87-154

Weisse T, Grimm N, Hickel W, Martens P (1986) Dynamics of Phaeocystis poucheti blooms in the Wadden Sea of Sylt (German Bight, North Sea). Estuar Coast Shelf Sci 23: $171-182$

Welschmeyer NA (1994) Fluorometric analysis of chlorophyll $a$ in the presence of chlorophyll $b$ and phaeopigments. Limnol Oceanogr 39:1985-1.992

Manuscript first received: February 16, 1996

Revised version accepted: November 19, 1996 